\title{
SKRINING FITOKIMIA, UJI AKTIVITAS ANTIOKSIDAN, DAN TOKSISITAS DARI EKSTRAK DAUN KERSEN (Muntingia calabura L.) DENGAN METODE 1.1-diphenyl-2-picrylhydrazyl (DPPH) dan Brine Shrimp Lethality Test (BSLT)
}

\author{
Selin R. Widjaya ${ }^{1)}$, Widdhi Bodhi ${ }^{1)}$, Adithya Yudistira ${ }^{1)}$ \\ ${ }^{1)}$ Program Studi Farmasi FMIPA UNSRAT Manado, 95116
}

\begin{abstract}
Kersen (Muntingia calabura L.) is a plant that has begun to be eliminated and was rarely used because it is often considered to have no economic value and lack of knowledge about its utilization, whereas kersen plants contain flavonoids, saponins, and tannins which were have high benefit for health. The content of metabolites is affected by soil nutrient elements and difference place of growth. This study aims to determine the potential of kersen leaves grown in North Minahasa based on phytochemical content, ability of antioxidant activity, and toxicity. Kersen leaves were extracted using sequential maceration method with n-hexane, ethyl acetate, and ethanol as solvents. Phytochemical Screening using several reagents which tailored to the type of phytochemical test. 1.1diphenyl-2-picrylhydrazyl (DPPH) method is used to evaluate antioxidant activity, and Brine Shrimp Lethality Test (BSLT) method is used to evaluate toxicity. The result of this study indicate that the nhexane extract contains phenols, flavonoids, and tannins, with $I C_{50}$ value $12.54 \mu \mathrm{g} / \mathrm{mL}$, and $L C_{50}$ value $881 \mu \mathrm{g} / \mathrm{mL}$. Ethyl acetate extract contains phenols, flavonoids, tannins, and saponins, with $I_{50}$ value $61.3 \mu \mathrm{g} / \mathrm{mL}$, and $L C_{50}$ value $1758 \mu \mathrm{g} / \mathrm{mL}$. Ethanol extract has phenol, flavonoid, tannin, saponin, and terpenoid content, with $I C_{50}$ value $9.01 \mu \mathrm{g} / \mathrm{mL}$, and $L C_{50}$ value $106 \mu \mathrm{g} / \mathrm{mL}$.
\end{abstract}

Keywords : Kersen leaves, Antioxidant, Toxicity, $I C_{50}, L C_{50}$

\begin{abstract}
ABSTRAK
Kersen (Muntingia calabura L.) merupakan tanaman yang sudah mulai tersingkirkan dan jarang dimanfaatkan karena sering dianggap tidak punya nilai ekonomis dan kurangnya pengetahuan tentang pemanfaatannya, padahal tanaman kersen memiliki kandungan flavonoid, saponin, dan tanin yang bermanfaat tinggi untuk kesehatan. Kandungan senyawa metabolit dipengaruhi oleh unsur hara tanah dan perbedaan tempat tumbuh. Penelitian ini bertujuan untuk mengetahui potensi dari daun kersen yang tumbuh di Minahasa Utara berdasarkan kandungan fitokimia, kemampuan aktivitas antioksidan, dan toksisitasnya. Ekstrak daun kersen diekstraksi dengan metode maserasi sekuensial menggunakan pelarut $\mathrm{n}$-heksan, etil asetat, dan etanol. Skrining fitokimia menggunakan beberapa reagen yang disesuaikan dengan jenis uji fitokimia. Metode 1.1-diphenyl-2-picrylhydrazyl (DPPH) digunakan untuk mengevaluasi aktivitas antioksidan, dan metode Brine Shrimp Lethality Test (BSLT) digunakan untuk mengevaluasi toksisitas. Hasil penelitian ini menunjukkan bahwa ekstrak n-heksan memiliki kandungan fenol, flavonoid, dan tanin, nilai $\mathrm{IC}_{50} 12,54 \mu \mathrm{g} / \mathrm{mL}$, dan nilai $\mathrm{LC}_{50} 881 \mu \mathrm{g} / \mathrm{mL}$. Ekstrak etil asetat memiliki kandungan fenol, flavonoid, tanin, dan saponin, nilai $\mathrm{IC}_{50} 61,3 \mu \mathrm{g} / \mathrm{mL}$, dan nilai $\mathrm{LC}_{50} 1758 \mu \mathrm{g} / \mathrm{mL}$. Ekstrak etanol memiliki kandungan fenol, flavonoid, tanin, saponin, dan terpenoid, nilai $\mathrm{IC}_{50} 9,01 \mu \mathrm{g} / \mathrm{mL}$, dan nilai $\mathrm{LC}_{50} 106 \mu \mathrm{g} / \mathrm{mL}$.
\end{abstract}

Kata kunci : Daun Kersen, Antioksidan, Toksisitas, $\mathrm{IC}_{50}, \mathrm{LC}_{50}$ 


\section{PENDAHULUAN}

Radikal bebas merupakan molekul yang sangat reaktif, sehingga dapat merusak struktur serta fungsi sel, dan mengakibatkan penyakit seperti kanker dan penyakit kardiovaskular (Balsano dan Alisi, 2009).

Antioksidan merupakan senyawa yang dapat menginaktivasi radikal bebas serta menghambat pembentukan radikal bebas baru dengan cara mendonorkan elektron dan mengikat radikal bebas. Di dalam tubuh manusia sudah terdapat antioksidan yang diproduksi secara alami oleh tubuh berupa enzim-enzim seperti superoksida dismutase, katalase, dan glutation peroksida yang dikenal sebagai antioksidan endogen (Youngson, 1998). Namun karena jumah radikal bebas yang masuk ke dalam tubuh melebihi kapasitas yang mampu dinetralisir oleh antioksidan alami dalam tubuh, maka diperlukan senyawa antioksidan eksogen. Berdasarkan penelitian yang telah dilakukan, penggunaan senyawa antioksidan sintetik dapat menyebabkan penyakit kronis seperti kanker dan kerusakan hati (Handayani dan Sulistyo, 2008). Maka dari itu perlu adanya sumber antioksidan alami yang efektif dan aman.

Kersen (Muntingia calabura L.) merupakan salah satu tanaman yang sudah mulai tersingkirkan karena sering dianggap tidak punya nilai ekonomis dan kurangnya pengetahuan tentang pemanfaatannya. Secara ilmiah daun kersen terbukti memiliki efek farmakologi antiulser (Ibrahim et al., 2012), aktivitas antipiretik dan anti-inflamasi (Zakaria et al., 2007).

Total kandungan senyawa metabolit suatu tanaman ditentukan oleh unsur hara tanah makro seperti Nitrogen
(N), Kalium (K), Bahan Organik (BO), dan Karbon organik (C) sehingga perbedaan unsur hara ini akan mempengaruhi senyawa yang terkandung dalam tanaman tersebut (Suryawati dan Murniyanto, 2011). Menurut penelitian yang dilakukan oleh Irawan dan Hidayah (2015), diketahui bahwa tanah di Minahasa Utara memiliki kandungan karbon organik dan nitrogen yang dapat dikategorikan tinggi, yaitu berturut-turut $3,6 \%$ dan $0,23 \%$.

Berdasarkan hal tersebut, peneliti bermaksud untuk mengetahui kandungan senyawa metabolit sekunder ekstrak daun kersen yang ada di Kabupaten Minahasa Utara, serta potensinya sebagai antioksidan dan toksisitasnya.

\section{METODOLOGI PENELITIAN}

Alat yang digunakan ialah ayakan 100 mesh, kertas saring (Whatman 42), tabung reaksi (Pyrex), rak tabung, pipet tetes, mikropipet $1000 \mu \mathrm{L}$ dan $200 \mu \mathrm{L}$ (SHCHEER), cawan petri (Pyrex), gelas piala (Iwaki), gelas ukur (Pyrex), labu takar (Iwaki), batang pengaduk, corong, alumunium foil, timbangan analitik (AE Adam), blender (Philips), vacuum rotary evaporator (Steroglass Strike 300) dan spektrofotometer UV-Vis (Shimazu).

Bahan yang digunakan ialah daun kersen, metanol, etanol, etil asetat, nheksan, DPPH, vitamin C, air laut, naupilus Artemia salina, aquadest, DMSO, $\mathrm{HCl}$ pekat, $\mathrm{FeCl}_{3} 1 \%$ dan $5 \%$, serbuk magnesium, reagen Dragendorf, kloroform, $\mathrm{CH}_{3} \mathrm{COOH}$ anhidrat, dan $\mathrm{H}_{2} \mathrm{SO}_{4}$ pekat.

PENGAMBILAN DAN PERSIAPAN SAMPEL 
Sampel yang digunakan ialah daun kersen (Muntingia calabura L.) yang diambil di desa Likupang, Minahasa Utara, Sulawesi Utara. Selanjutnya sampel dibersihkan dan dikering anginkan hingga sampel kering. Setelah kering sampel diblender hingga sampel menjadi halus lalu diayak dengan ayakan 100 mesh.

\section{IDENTIFIKASI TANAMAN}

Identifikasi tanaman dilakukan di Bagian Taksonomi Tumbuhan Program Studi Biologi Fakultas Matematika dan Ilmu Pengetahuan Alam, Universitas Sam Ratulangi.

\section{EKSTRAKSI DAN FRAKSINASI}

Ekstraksi bahan aktif dilakukan dengan metode maserasi menggunakan pelarut n-heksan, etil asetat, dan etanol 96\% selama 24 jam. Serbuk daun kersen (Muntingia calabura L.) ditimbang sebanyak 200 gram dan dimasukkan ke dalam baker glass, kemudian ditambahkan pelarut n-heksan hingga volume akhir mencapai $800 \mathrm{~mL}$ dengan perbandingan 1 : 4 (w/v). Hasil maserasi kemudian disaring dengan kertas saring sehingga dihasilkan filtrat n-heksan dan residu. Residu yang diperoleh ditambahkan pelarut etil asetat hingga hingga volume akhir mencapai $800 \mathrm{~mL}$ dengan perbandingan $1: 4(\mathrm{w} / \mathrm{v})$. Hasil maserasi kemudian disaring dengan kertas saring sehingga dihasilkan filtrat etil asetat dan residu. Residu yang diperoleh ditambahkan pelarut etanol $96 \%$ hingga hingga volume akhir mencapai $800 \mathrm{~mL}$ dengan perbandingan $1: 4(\mathrm{w} / \mathrm{v})$. Hasil maserasi kemudian disaring dengan kertas saring sehingga dihasilkan filtrat etanol 96\% dan residu. Perendaman dengan masing-masing pelarut dilakukan remaserasi sebanyak 1 kali. Filtrat etanol $96 \%$, etil asetat, dan n-heksan yang diperoleh kemudian dipekatkan dengan evaporator pada suhu $40^{\circ} \mathrm{C}$ hingga diperoleh tiga ekstrak kental.

\section{SKRINING FITOKIMIA}

Skrining fitokimia ekstrak etanol $96 \%$, etil asetat, dan n-heksan daun kersen (Muntingia calabura L.) meliputi senyawa yang berpotensi sebagai antioksidan dan berpotensi toksik, yaitu pemeriksaan gologan fenol, flavonoid, dan alkaloid berdasarkan Harbone (1987), golongan tanin berdasarkan Sangi dkk. (2008), golongan saponin berdasarkan Depkes RI (1979), dan terpenoid berdasarkan Padmasari dkk. (2013).

\section{UJI AKTIVITAS ANTIOKSIDAN DENGAN METODE DPPH}

Untuk pengujian dengan metode DPPH menggunakan metode yang dikemukakan oleh Molyneux (2004), yakni masing-masing larutan stok ekstrak etanol $96 \%$ etil asetat, dan n-heksan daun kersen (Muntingia calabura L.) dibuat konsentrasi $1000 \mu \mathrm{g} / \mathrm{mL}$ dengan cara sebanyak masing-masing $10 \mathrm{mg}$ ekstrak etanol $96 \%$ etil asetat, dan n-heksan daun kersen (Muntingia calabura L.), masingmasing dimasukkan ke dalam $10 \mathrm{~mL}$ pelarutnya. Masing-masing ekstrak etanol $96 \%$, etil asetat, dan n-heksan daun kersen (Muntingia calabura L.) dibuat dalam beberapa konsentrasi, yaitu $10 \mu \mathrm{g} / \mathrm{mL}, 20$ $\mu \mathrm{g} / \mathrm{mL}, \quad 30 \mu \mathrm{g} / \mathrm{mL}, 40 \mu \mathrm{g} / \mathrm{mL}$, dan 50 $\mu \mathrm{g} / \mathrm{mL}$ untuk ekstrak etil asetat, serta konsentrasi $2 \mu \mathrm{g} / \mathrm{mL}, 4 \mu \mathrm{g} / \mathrm{mL}, 6 \mu \mathrm{g} / \mathrm{mL}, 8$ $\mu \mathrm{g} / \mathrm{mL}$, dan $10 \mu \mathrm{g} / \mathrm{mL}$ untuk ekstrak heksan dan etanol $96 \%$. 
a. Konsentrasi $50 \mu \mathrm{g} / \mathrm{mL}$ dibuat dengan cara diambil $0,5 \mathrm{~mL}$ larutan stok dan dimasukkan ke dalam 9,5 $\mathrm{mL}$ pelarutnya.

b. Konsentrasi $40 \mu \mathrm{g} / \mathrm{mL}$ dibuat dengan cara diambil $0,4 \mathrm{~mL}$ larutan stok dan dimasukkan ke dalam 9,6 $\mathrm{mL}$ pelarutnya.

c. Konsentrasi $30 \mu \mathrm{g} / \mathrm{mL}$ dibuat dengan cara diambil $0,3 \mathrm{~mL}$ larutan stok dan dimasukkan ke dalam $9,7 \mathrm{~mL}$ pelarutnya.

d. Konsentrasi $20 \mu \mathrm{g} / \mathrm{mL}$ dibuat dengan cara diambil 0,2 $\mathrm{mL}$ larutan stok dan dimasukkan ke dalam 9,8 $\mathrm{mL}$ pelarutnya.

e. Konsentrasi $10 \mu \mathrm{g} / \mathrm{mL}$ dibuat dengan cara diambil $0,1 \mathrm{~mL}$ larutan stok dan dimasukkan ke dalam 9,9 $\mathrm{mL}$ pelarutnya.

Larutan DPPH $0,4 \mathrm{mM}$ dibuat dengan cara ditimbang 7,88 $\mathrm{mg}$ DPPH (BM 394,32 g/mol) dilarutkan dengan metanol hingga $50 \mathrm{~mL}$ dalam labu takar 50 $\mathrm{mL}$ di tempat gelap. Kedalam tiap tabung reaksi ditambahkan $1 \mathrm{~mL}$ larutan DPPH 0,4 mM dalam metanol. Masing-masing ekstrak etanol 96\%, ekstrak etil asetat, dan ekstrak n-heksan berbagai konsentrasi dimasukkan kedalam tabung reaksi yang telah diisi $1 \mathrm{~mL}$ larutan DPPH 0,4 mM dalam metanol, sampai volume $5 \mathrm{~mL}$, kemudian diinkubasi pada suhu $27^{\circ} \mathrm{C}$ selama 30 menit selanjutnya serapan diukur dengan spektrofotometer UV-Vis pada panjang gerombang $517 \mathrm{~nm}$. Vitamin $\mathrm{C}$ digunakan sebagai pembanding dengan konsentrasi $2 \mu \mathrm{g} / \mathrm{mL}, 4 \mu \mathrm{g} / \mathrm{mL}, 6 \mu \mathrm{g} / \mathrm{mL}, 8$ $\mu \mathrm{g} / \mathrm{mL}, 10 \mu \mathrm{g} / \mathrm{mL}$.

\section{UJI TOKSISITAS DENGAN METODE} BSLT
Pengujian tuksisitas ekstrak daun Solanum tuberosum menggunakan metode Brine Shrimp Lethality Test (BSLT) yang mengacu pada Meyer et al. (1982) dan Krishnaraju et al. (2005) dengan cara mengujikan senyawa yang diduga toksik terhadap larva A. salina.

\section{PENYIAPAN LARVA Artemia salina}

Penetasan telur A. salina dilakukan dengan cara sebanyak $100 \mathrm{mg}$ telur $A$. salina direndam dalam wadah yang berisi air laut dibawah cahaya lampu 25 watt. Telur A. salina akan menetas dan menjadi larva kurang lebih setelah 24 jam. Setelah berumur 48 jam larva udang siap digunakan untuk uji toksisitas (Halimah, 2010).

\section{PEMBUATAN KONSENTRASI SAMPEL UJI}

Pembuatan konsentrasi larutan uji untuk BSLT adalah $1000 \mu \mathrm{g} / \mathrm{mL}, 100$ $\mu \mathrm{g} / \mathrm{mL}, 10 \mu \mathrm{g} / \mathrm{mL}, 1 \mu \mathrm{g} / \mathrm{mL}$, dan $0 \mu \mathrm{g} / \mathrm{mL}$ (sebagai kontrol negatif) sesuai metode yang dipakai oleh Surya (2018).

a. Masing-masing ekstrak etanol 96\%, etil asetat, dan n-heksan daun kersen (Muntingia calabura L.) ditimbang sebanyak $50 \mathrm{mg}$, kemudian dilarutkan dengan air laut sebanyak $50 \mathrm{~mL}$ untuk memperoleh konsentrasi $1000 \mu \mathrm{g} / \mathrm{mL}$.

b. Dari larutan dengan konsentrasi 1000 $\mu \mathrm{g} / \mathrm{mL}$ diambil $5 \mathrm{~mL}$ dan dilarutkan dengan air laut hingga $50 \mathrm{~mL}$ untuk mendapatkan konsentrasi $100 \mu \mathrm{g} / \mathrm{mL}$.

c. Dari larutan dengan konsentrasi 100 $\mu \mathrm{g} / \mathrm{mL}$ diambil $5 \mathrm{~mL}$ dan dilarutkan dengan air laut hingga $50 \mathrm{~mL}$ untuk mendapatkan konsentrasi $10 \mu \mathrm{g} / \mathrm{mL}$.

d. Dari larutan dengan konsentrasi 10 $\mu \mathrm{g} / \mathrm{mL}$ diambil $5 \mathrm{~mL}$ dan dilarutkan 
dengan air laut hingga $50 \mathrm{~mL}$ untuk mendapatkan konsentrasi $1 \mu \mathrm{g} / \mathrm{mL}$.

e. Untuk mendapatkan larutan konsentrasi $0 \mu \mathrm{g} / \mathrm{mL}$ dibuat dengan mengambil $10 \mathrm{~mL}$ air laut.

\section{PELAKSANAAN UJI TOKSISITAS}

Masing-masing konsentrasi dari tiap ekstrak dilakukan uji toksisitas dengan 3 replikasi menggunakan 10 ekor larva $A$. salina pada setiap kelompok uji. Sebanyak 45 wadah yang telah diisi masing-masing 10 ekor larva A. salina disiapkan. Ekstrak etanol $96 \%$, etil asetat, dan n-heksan masing-masing menggunakan 15 wadah. Sebanyak 3 wadah digunakan untuk konsentrasi $100 \mu \mathrm{g} / \mathrm{mL}, 3$ wadah untuk konsentrasi $10 \mu \mathrm{g} / \mathrm{mL}, 3$ wadah untuk konsentrasi $1 \mu \mathrm{g} / \mathrm{mL}$, dan 3 wadah untuk konsentrasi $0 \mu \mathrm{g} / \mathrm{mL}$ sebagai kontrol negatif. Pengamatan dilakukan selama 24 jam terhadap kematian larva A. salina. Kriteria standar untuk menilai kematian larva A. salina yaitu bila larva A. salina tidak menunjukkan pergerakkan selama beberapa detik observasi (Meyer et al., 1982; Krishnaraju et al., 2005).

\section{ANALISIS DATA}

Data hasil penelitian akan diolah dan disajikan dalam bentuk tabel dan grafik. Data dari uji antioksidan dan toksisitas akan dianalisis dengan analisis regresi linier menggunakan Microsoft Excel 2013 untuk menentukan nilai $\mathrm{IC}_{50}$ dan $\mathrm{LC}_{50}$.

\section{HASIL DAN PEMBAHASAN EKSTRAKSI DAN FRAKSINASI}

Sampel yang digunakan dalam penelitian ini adalah daun kersen yang diambil di Likupang, Kabupaten Minahasa
Utara. Sebelum dilakukan proses ekstraksi, sampel dicuci dan dikeringkan kemudian diserbukkan dengan menggunakan alat blender dan diayak dengan ayakan 100 mesh. Proses pencucian sampel bertujuan memisahkan bahan asing yang menempel pada sampel. Proses pengeringan sampel bertujuan untuk menghilangkan kadar air dalam sampel karena dapat mengganggu proses penarikan zat aktif, dan kadar air yang tinggi juga dapat membuat sampel mudah rusak oleh adanya pertumbuhan jamur. Proses penyerbukkan bertujuan memperbesar luas permukaan kontak dengan pelarut sehingga mengoptimalkan proses ekstraksi. Proses pengayakan bertujuan menyeragamkan ukuran partikel yang mempengaruhi keseragaman tahapan ekstraksi zat aktif.

Proses ekstraksi serbuk daun kersen dilakukan dengan cara maserasi sekuensial menggunakan tiga jenis pelarut yang berbeda tingkat kepolarannya, dari yang kurang polar ke polar, yaitu nheksan, etil asetat, dan etanol 96\%. Maserasi dilakukan selama 3 x 24 jam pada suhu kamar dengan satu kali remaserasi tiap pelarut dan diaduk sekali sehari. Penggunaan metode maserasi dipilih karena selain mudah dan murah, perendaman yang lama memungkinkan terjadi pemecahan dinding dan membran sel akibat perbedaan tekanan di dalam dan di luar sel, sehingga metabolit sekunder yang ada dalam sitoplasma akan terlarut dalam pelarut (Harbone, 1987).

Metode maserasi dilakukan secara sekuansial supaya selama proses maserasi, komponen yang diekstraksi sekaligus terfraksinasi berdasarkan kepolarannya. Penggunaan pelarut n-heksan untuk melarutkan senyawa yang non-polar, sedangkan etil asetat untuk melarutkan 
senyawa semipolar, dan etanol $96 \%$ untuk melarutkan senyawa yang lebih polar. Selama perendaman dilakukan sesekali pengadukan untuk menyeragamkan konsentrasi zat aktif dalam pelarut.

SKRINING FITOKIMIA

\begin{tabular}{ll}
\hline Sampel & $\mathrm{IC}_{50}(\mu \mathrm{g} / \mathrm{mL})$ \\
\hline Ekstrak Heksan & 12,54 \\
\hline Ekstrak Etil Asetat & 61,30 \\
\hline Ekstrak Etanol & 9,01 \\
\hline Vitamin C & 8,32 \\
\hline
\end{tabular}

Skrining fitokimia bertujuan untuk mengetahui kandungan golongan senyawa suatu tumbuhan sebagai informasi awal untuk meramalkan aktivitas biologi. Skrining fitokimia dalam penelitian ini

\begin{tabular}{cccc}
\hline Senyawa & $\begin{array}{c}\text { Ekstrak } \\
\text { metabolit }\end{array}$ & $\begin{array}{c}\text { Ekstrak } \\
\text { heksan }\end{array}$ & $\begin{array}{c}\text { Ekstrak } \\
\text { etanol } \\
\text { asetat }\end{array}$ \\
& &
\end{tabular}

\begin{tabular}{cccc}
\hline Fenol & + & + & + \\
\hline Flavonoid & + & + & + \\
\hline Tanin & + & + & + \\
\hline Saponin & - & + & +
\end{tabular}

\begin{tabular}{llll}
\hline Alkaloid & - & - & - \\
\hline Terpenoid & - & + & +
\end{tabular}

dilakukan untuk menguji ada tidaknya enam golongan senyawa yang berpotensi sebagai antioksidan dan berpotensi toksik, yaitu fenol, flavonoid, tanin, saponin, alkaloid, dan terpenoid. Hasil penujian fitokimia dapat dilihat pada Tabel 1 .

Tabel 1. Hasil skrining fitokimia

\section{UJI AKTIVITAS ANTIOKSIDAN DENGAN METODE DPPH}

Pengujian aktivitas antioksidan dengan metode DPPH yang diperkenalkan oleh Molyneux (2004) dilakukan dengan mereaksikan larutan ekstrak berbagai konsentrasi dengan larutan DPPH yang

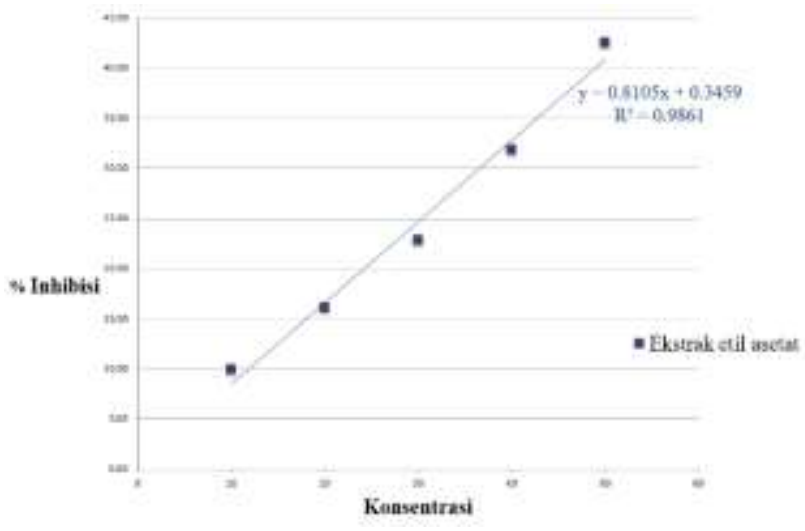

selanjutnya dibaca absorbansinya dengan spektrofotometer UV-Vis pada panjang gelombang $517 \mathrm{~nm}$. Hasil pengujian aktivitas antioksidan dapat dilihat pada Tabel 2.

Tabel 2. Perbandingan aktivitas antioksidan

Gambar 1. Grafik aktivitas penangkal radikal bebas ekstrak etil asetat

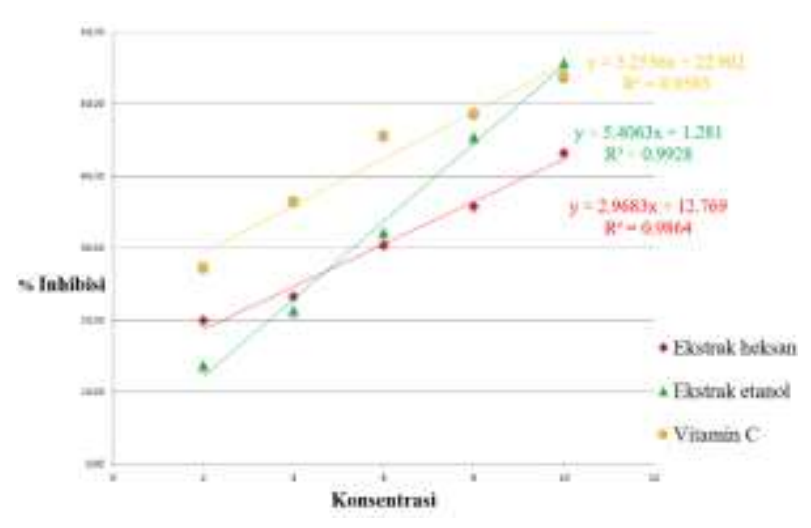

Gambar 2. Grafik aktivitas penangkal radikal bebas ekstrak heksan, ekstrak etanol, dan vitamin $\mathrm{C}$

Pada pengujian terhadap DPPH diketahui bahwa aktivitas antioksidan 
paling kuat terjadi pada ekstrak etanol dimana pada konsentrasi 9,01 $\mu \mathrm{g} / \mathrm{mL}$ sudah dapat menghilangkan setengah karakteristik radikal dari DPPH. Aktivitas antioksidan tertinggi berikutnya diikuti ekstrak n-heksan sebesar $12,47 \mu \mathrm{g} / \mathrm{mL}$ dan ekstrak etil asetat sebesar $61,30 \mu \mathrm{g} / \mathrm{mL}$. Hal ini membuktikan bahwa pelarut etanol merupakan perlarut yang paling efektif dalam mengikat senyawa aktif yang berfungsi sebagai antioksidan yang terdapat pada daun kersen.

Berdasarkan perubahan warna yang terjadi dapat diketahui bahwa ekstrak etanol dan ekstrak n-heksan mempunyai aktivitas antioksidan yang sangat kuat, hal ini ditunjukkan dengan perubahan warna larutan dari ungu menjadi kuning pucat yang terjadi dengan cepat, sedangkan pada ekstrak etil asetat perubahan warna terjadi secara perlahan dan tidak mencapai wana kuning pucat. Adanya perubahan warna ini disebabkan ketika larutan DPPH dicampur dengan senyawa yang dapat mendonasikan atom hidrogen, maka DPPH berubah menjadi bentuk tereduksi (1,1-difenil-2pikrihidrazin) dengan kehilangan warna violet menjadi warna kuning. Perubahan warna kuning ini menghasilkan senyawa bukan radikal (1,1-difenil-2-pikrihidrazin) dan radikal (A) (Suryanto, 2012).

Antioksidan yang digunakan sebagai pembanding ialah Vitamin $\mathrm{C}$. Nilai $\mathrm{IC}_{50}$ dari Vitamin $\mathrm{C}$ didapat sebesar $8,32 \mu \mathrm{g} / \mathrm{mL}$, nilai ini menunjukkan bahwa kemampuan penangkal radikal bebas Vitamin C lebih kuat dibandingkan ekstrak n-heksan $(12,47 \mu \mathrm{g} / \mathrm{mL})$, ekstrak etil asetat $(61,30 \mu \mathrm{g} / \mathrm{mL})$, maupun ekstrak etanol $(9,01 \mu \mathrm{g} / \mathrm{mL})$ daun kersen. Menurut Molyneux (2004), antioksidan dikatakan sebagai antioksidan dengan aktivitas sangat kuat ketika nilai $\mathrm{IC}_{50}$ kurang dari 50 $\mu \mathrm{g} / \mathrm{mL}\left(\mathrm{IC}_{50}<50 \mu \mathrm{g} / \mathrm{mL}\right)$, kuat $(50 \mu \mathrm{g} / \mathrm{mL}$ $\left.<\mathrm{IC}_{50}<100 \mu \mathrm{g} / \mathrm{mL}\right)$, sedang $(100 \mu \mathrm{g} / \mathrm{mL}$ $\left.<\mathrm{IC}_{50}<150 \mu \mathrm{g} / \mathrm{mL}\right)$, lemah $(150 \mu \mathrm{g} / \mathrm{mL}<$ $\mathrm{IC}_{50}<200 \mu \mathrm{g} / \mathrm{mL}$ ), dan sangat lemah ( $\mathrm{IC}_{50}$ $>200 \mu \mathrm{g} / \mathrm{mL}$ ). Hal ini menunjukkan bahwa vitamin $\mathrm{C}$, ekstrak n-heksan dan ekstrak etanol daun kersen merupakan antioksidan dengan aktivitas sangat kuat, sedangkan ekstrak etil asetat merupakan antioksidan dengan aktivitas kuat.

\section{UJI TOKSISITAS DENGAN METODE BSLT}

Uji toksisitas menggunakan metode BSLT dipilih karena efek toksik suatu senyawa dapat ditentukan dalam waktu singkat, mudah dikerjakan, murah, cukup akurat, dan hanya membutuhkan sejumlah kecil material (Meyer et al., 1982). Hewan uji yang digunakan yaitu larva Artemia salina L. yang berumur 48 jam karena pada umur ini larva sudah memiliki organ yang terbentuk lengkap sehingga lebih peka terhadap suatu senyawa (Panjaitan, 2011). Hasil pengujian toksisitas ekstrak daun kersen dengan metode BSLT dapat dilihat pada tabel 3 .

Tabel 3. Perbandingan nilai $\mathrm{LC}_{50}$

\begin{tabular}{lc}
\hline \multicolumn{1}{c}{ Sampel } & $\mathrm{LC}_{50}(\mu \mathrm{g} / \mathrm{mL})$ \\
\hline Ekstrak Heksan & 881 \\
\hline Ekstrak Etil Asetat & 1758 \\
\hline Ekstrak Etanol & 106
\end{tabular}

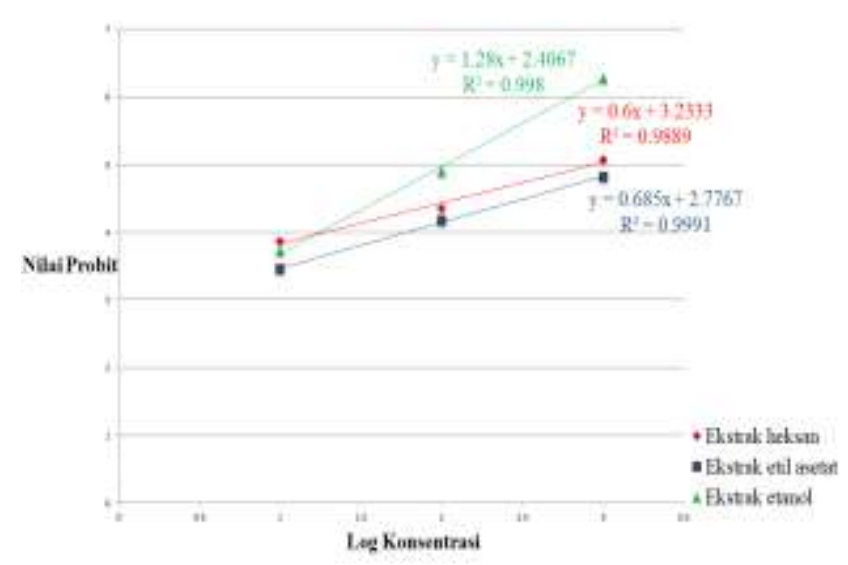


Gambar 3. Grafik analisis probit

Berdasarkan tabel diatas diketahui bahwa ekstrak heksan, ekstrak etil asetat, maupun ekstrak etanol $96 \%$ menunjukkan tingkat kematian larva semakin tinggi berbanding lurus dengan semakin tingginya konsentrasi. Persentase kematian larva paling tinggi terjadi pada konsentrasi $1000 \mu \mathrm{g} / \mathrm{mL}$, dan persentase kematian terendah terjadi pada konsentrasi $1 \mu \mathrm{g} / \mathrm{mL}$. Pada kontrol negatif tidak terjadi kematian, sehingga dapat dikatakan bahwa kematian larva bukan dikarenakan pengaruh air laut, melainkan karena ekstrak yang diberikan.

Hasil analisis probit menggunakan persamaan regresi linear menunjukkan bahwa nilai $\mathrm{LC}_{50}$ ekstrak n-heksan, ekstrak etil asetat, dan ekstrak etanol 96\% berturut-turut $881 \mu \mathrm{g} / \mathrm{mL}, 1762 \mu \mathrm{g} / \mathrm{mL}$, dan $106 \mu \mathrm{g} / \mathrm{mL}$. Menurut Meyer et al (1982), ekstrak dikatakan bersifat toksik apabila memiliki nilai $\mathrm{LC}_{50}$ dengan konsentrasi kurang dari $1000 \mu \mathrm{g} / \mathrm{mL}$, sehingga dapat dikatakan ekstrak n-heksan dan ektrak etanol daun kersen termasuk kategori toksik. Di antara ketiga ekstrak didapati ekstrak etanol bersifat paling toksik diikuti dengan ekstrak n-heksan, dan ekstrak etil asetat.

Terpenoid dan alkaloid merupakan senyawa penyebab adanya sifat toksik. Berdasarkan skrining fitokimia yang dilakukan didapati ekstrak etanol positif mengandung terpenoid dan negatif mengandung alkaloid, sedangkan ekstrak yang lainnya negatif mengandung terpenoid maupun alkaloid.

Kemampuan ekstrak menyebabkan kematian larva udang melalui mekanisme stomach poisoning (racun perut), dimana larva mengalami gangguan pada saluran cernanya serta reseptor permukaan mulut larva dihambat sehingga larva tidak bisa mendeteksi makanan dan mati kelaparan (Meyer et al, 1982).

\section{KESIMPULAN}

Ekstrak n-heksan daun kersen (Muntingia calabura) memiliki senyawa metabolit sekunder fenol, flavonoid, tanin, sedangkan ekstrak etil asetat memiliki metabolit sekunder fenol, flavonoid, tanin, saponin, serta ekstrak etanol 96\% memiliki metabolit sekunder fenol, flavonoid, tanin, saponin, dan terpenoid.

Ekstrak n-heksan daun kersen (Muntingia calabura) memiliki aktivitas antioksidan sangat kuat dengan $\mathrm{IC}_{50}$ sebesar $12,47 \mu \mathrm{g} / \mathrm{mL}$, ekstrak etil asetat memiliki aktivitas antioksidan kuat dengan $\mathrm{IC}_{50}$ sebesar $61,30 \mu \mathrm{g} / \mathrm{mL}$, dan ekstrak etanol memiliki aktivitas antioksidan sangat kuat dengan $\mathrm{IC}_{50}$ sebesar 9,01 $\mu \mathrm{g} / \mathrm{mL}$,

Ekstrak n-heksan daun kersen (Muntingia calabura) memiliki sifat toksik dengan $\mathrm{LC}_{50}$ sebesar $881 \mu \mathrm{g} / \mathrm{mL}$, ekstrak etil asetat memiliki sifat yang relatif tidak toksik dengan $\mathrm{LC}_{50}$ sebesar $1758 \mu \mathrm{g} / \mathrm{mL}$, dan ekstrak etanol $96 \%$ memiliki sifat toksik dengan $\mathrm{LC}_{50}$ sebesar $106 \mu \mathrm{g} / \mathrm{mL}$

\section{SARAN}

Dengan hasil penelitian ini perlu dilakukan penelitian lebih lanjut mengenai hubungan kandungan total fenol dan flavonoid dengan aktivitas antioksidan yang sangat kuat dari ekstrak daun kersen, serta isolasi senyawa bioaktifnya.

\section{DAFTAR PUSTAKA}

Balsano, C., Alisi, A. 2009. Antioxidant Effect of Natural Bioactive Compounds. Current 
Pharmaceutical Design. 15: 30633073.

Depkes RI. 1979. Materia Medika Indonesia Edisi III. Direktorat Pengawasan Obat dan Makanan. Depkes RI, Jakarta.

Halimah, N. 2010. Uji Fitokimia dan Uji Toksisitas Ekstrak Tanaman Anting-Anting (Acalypha indica L.) terhadap Larva Udang Artemia salina L. [Skripsi]. Fakultas Sains dan Teknologi, Universitas Islam Negeri Maulana Malik Ibrahim Malang.

Handayani, R., Sulistyo, J. 2008. Sintesis Senyawa Flavonoid- $\alpha$-Glikosida Secara Reaksi Transglikosilasi Enzimatik dan Aktivitasnya sebagai Antioksidan. Biodiversitas. 9(1): $1-4$.

Harborne, J. B. 1987. Metode Fitokimia Edisi ke-2. ITB Press, Bandung.

Ibrahim, I. A.A., Abdulla, M.A., Abdelwahab, S. I., Al-Bayataty, F., Majid, N.A. 2012. Leaves Extract of Muntingia calabura Protects Against Gastric Ulcer Induced by Ethanol in Sprague-dawley Rats. Clinical and Experimental Phamacology, USA.

Krishnaraju A. V., Rao., Sundraraju, A. 2005. Assestment of Biooctivity of Indian Medical Plants tlsing Brine Shrimp (Artemia salina) Lethality Assay. International Journal Applied Science and Engineering. 2: 125-134.
Meyer, B. N., Ferrigni, N. R., Putnam, J. E., Jacobsen, L. B., Nichols, D. E., Mclaughin, J. L. 1982. Brine Shrimp: A Cowenient General Bioassay for Active Plant Constituenls. Planta Medica. 45:31-34.

Molyneux, P. 2004. The Use of The Stable Free Radical diphenylpicrylhydrazyl (DPPH) for Estimating Antioxidant Activity. Songklanakarin Journal Science Technology. 26(2): 211-219.

Padmasari, P. D., Astuti, K. W., Warditiani, N. K. 2013. Skrining Fitokimia Ekstrak Etanol 70\% Rimpang Bangle (Zingiber purpureum). Jurnal Farmasi Udayana. 2(4): 1-4.

Panjaitan, R. B. 2011. Uji Toksisitas Akut Kulit Batang Pulasari (Alyxiae cortex) dengan Metode Brine Shrimp Lethality Test (BSLT). [Skripsi]. Fakultas Kedokteran, Universitas Sanata Dharma Yogyakarta.

Sangi, M., Runtuwene, M. R. J., Simbala, H. E. I., Makang, V. M. A. 2008. Analisis Fitokimia Tumbuhan Obat di Kabupaten Minahasa Utara. Chemistry Progress. 1(1).

Surya, A. 2018. Toksisitas Ekstrak Metanol Kulit Jengkol (Pithecellobium Jiringa) dengan Metode Brine Shrimp Lethality Test terhadap Larva Udang (Artemia salina). Jurnal Rekayasa Sistem Industri. 3(2): 149-153. 
Suryanto, E. 2012. Fitokimia Antioksidan. Putra Media Nusantara, Surabaya.

Suryawati, S., Murniyanto, E. 2011. Hubungan Sifat Tanah Madura dengan Kandungan Minyak Atsiri dan Tingkat Kelarutannya pada Jahe (Zingiber offocinale L.). Agrovigor. 4(2): 33-41.

Youngson, R. 1998. Antioxidants: Vitamins $C$ \& $E$ for Health. Sheldon Press, Great Britain.

Zakaria, Z. A., Nor Hazalin, A. M. N., Zaid, S. N. H. M., Ghani, M. A., Hassan, M. H., Gopalan, H. K., Sulaiman, M. R. 2007. Antinociceptive, AntiInflammatory and Antipyretic Effects of Muntingia calabura Aqueous Extract in Animal Models. Journal of Natural Medicines. 61(4): 443-448. 